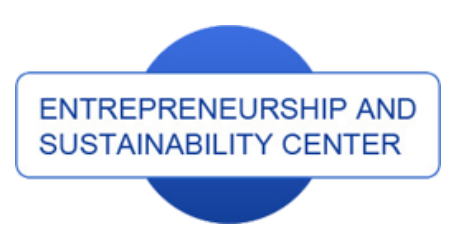

Publisher

http://jssidoi.org/esc/home

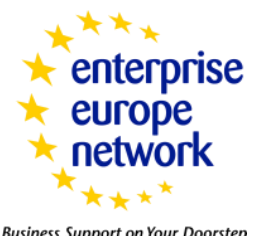

Business Support on Your Doorstep
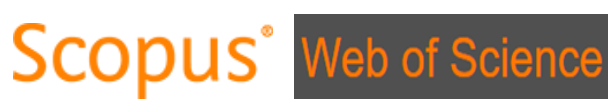

1) Clarivate

\title{
MODEL BASED ON QUALITATIVE CRITERIA FOR INTERNET MARKETING DEVELOPMENT
}

\author{
Tadas Limba1, Mindaugas Kiškis ${ }^{2}$, Gintarè Gulevičiūtė ${ }^{3}$, Andrius Stasiukynas ${ }^{4}$, Tomas Plèta ${ }^{5}$, Ieva \\ Juozapavičiūtè
}

\author{
1,2, 3,4, 5, 6 Mykolas Romeris University \\ Ateities str. 20, 08303 Vilnius, Lithuania

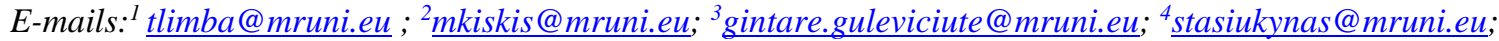
ppleta.tomas@gmail.com; ${ }^{6}$ i.juozapaviciute@gmail.com
\end{abstract}

Received 16 September 2017; accepted 15 January 2018; published 30 March 2018

\begin{abstract}
Purpose of this paper is to propose a model for assessment of internet marketing efficacy, based on qualitative criteria and building on the theoretical and empirical investigation of various qualitative criteria applicable to internet marketing. The methodological framework used in the investigation is based on theoretical descriptive, comparative, analytical methods. Qualitative empirical study based on expert interviews was also employed. Nine experts of internet marketing and related fields were involved in the study. The aim of qualitative study is to explore the expert opinnions on the qualitative criteria for internet marketing assessment. This feedback helps to identify problems faced by business developing internet marketing campaigns, the steps to be taken further to solve them and advance campaign efficacy. The model integrating the qualitative criteria into the internet marketing assessment is proposed. The paper analyses the creation and application of qualitative criteria of internet marketing, discusses the problems of internet marketing development, proposes the ways how to deal with the emerging problems and presents the qualitative criteria based model for internet marketing assesment. The qualitative study is the main novety of the research and is intended to scrutinise the concept of internet marketing quality and distinguish the qualitative criteria for internet marketing development.The conclusions and recommendations of the research have practical value, which will help in the process of internet marketing quality implementation.
\end{abstract}

Keywords: internet marketing, qualitative criteria of internet marketing, qualitative study.

Reference to this paper should be made as follows: Limba, T.; Kiškis, M; Gulevičiūtè, G.; Stasiukynas, A.; Plèta, T.; Juozapavičiūtè, I. 2018. Model Based on Qualitative Criteria for Internet Marketing Development, Entrepreneurship and Sustainability Issues 5(3): 618-633. http://doi.org/10.9770/jesi.2018.5.3(15)

JEL Classifications: M31, M37, L81

Additional disciplines: information and communication 


\section{Introduction}

XXI century is regarded as the most important global information technology revolution in the world. Modern people live in the world of technologies that are rapidly improving and expanding into different areas. This phenomenon leads to the growing needs of people and competition. Constantly changing environment of new business models, organizational forms, and the migration of business into the electronic environment is nothing strange, it becomes mandatory part of everyday life.

The Internet and other digital media tools have transformed marketing. Smart growth have contributed to expansion of service sector (Tvaronavičienè, 2017). The customers have much broader choice of goods and services, they can choose between wide number of suppliers and prices. New internet marketing opportunities provide new challenges to organizations too. They might to expand, provide new services; in short, organizations have great opportunities to win competitive advantages (Chaffey et al., 2009). Revolution of internet marketing creates a necessitaty to a radical rethinking of marketing practice (Balmer, Yen, 2017).

Scientific issue - after the Internet transformed marketing, the business opportunities are increasing and internet marketing for business becomes one of the most important tools to reach competitive advantage. In order to reach it there is a need to determine the qualitative criteria of internet marketing that influence business and consumers. Thus, the problem is that the concept of internet marketing quality and the qualitative criteria are not determined by scientific literature as well as the practice, which makes difficulty to determine the effectiveness of internet marketing.

The gooal of the research is to propose a model for assessment of internet marketing efficacy, based on qualitative criteria and building on the theoretical and empirical investigation of various qualitative criteria applicable to internet marketing.

The goal will be achieved through the following set of tasks:

1. To analyse theoretical aspects of internet marketing qualitative criteria.

2. To perform the qualitative study based on expert interviews regarding consumers' and business' approach of emerging qualitative criteria for internet marketing.

3. Based on theoretical part and qualitative study results, to design the internet marketing qualitative criteria based model.

Methodology - the paper relies on scientific literature analysis, the qualitative research method and the method of dynamic modeling are applied as well. The work carried out theoretical narrative, systematic, comparative analysis. A qualitative expert opinion survey was carried out interviewing e-marketing experts. The experts' opinion was sought to analyze by a standardized interview or questionnaire form. After analysis there was created a model.

The Internet provides tremendous opportunities to reduce the cost of information distribution to global audience. Internet marketing is a key element of developing successful electronic business marketing strategies for large and small companies. Internet marketing allows Lithuania and any other countrys' businesses to compete in international markets, saving money for traditional advertising. Moreover, internet marketing is orientated to individuals and the target users according to their hobbies or activities (Išoraite, 2013). New tendencies are based on data-driven marketing communications and customer management (Deighton, 2017). Internet marketing 
adoption in emerging industrial markets are based on internet technologies such as social media platforms, static and transactional websites (Shaltoni, 2017). Social networks becomes especially important in in B2B and B2C Communication (Davidavičienė et al., 2017; Davidavičienė, Davidavičius, 2014).

Moving the business to e. environment is one of the steps, but in order to become a successful business it has to attract the costumers and within a website to build strong and good relationship with consumer (Fisher et al., 2003), it must have one of the most important tools - strong marketing team. One of the most important internal barriers impacting internationalization of SMEs is limited management skills, communication issues and lack of marketing knowledge (Tvaronavičienè, Korsakienè, 2012). XXI century has become a very significant to marketing professionals. Collision with a number of innovations, challenges and opportunities caused by traditional marketing to the electronic transition. In the literature, this marketing direction is also called internet marketing, web - marketing, hyper - marketing.

\section{The concept and evaluation of internet marketing}

The concept of marketing is widespread in the world. On the one hand it has a significant value in terms of successful organizations'life. On the other hand in recent decade business strategy has changed and in order to satisfy more customers' needs it has moved to e. business. As a result, marketing has also moved from traditional to internet marketing. Although the concept of internet marketing is analysed much, but still there is no concept of internet marketing quality and qualitative criteria of internet marketing determination. Overall, there is a wide choice of internet marketing concepts such as (Juozapavičiūtè, 2015):

- To the advertising industry it is about Internet advertising and its impact on driving Web traffic and brand building (Breakenridge, 2001).

- The application of the Internet and related digital technologies conjunction with traditional communications to achieve marketing objectives (Chaffey et al., 2009).

- Internet marketing is linked to as the marketing (generally promotion) of products and services over the Internet (Chaffey, 2014).

However, a core, unifying concept of internet marketing has not emerged.

Internet marketing is becoming one of the most effective way to satisfy growing consumers' expectations and to develop business. There are many forms of internet marketing, which enables companies to attract more users and affect their opinion. The functions of internet marketing are as follows (Išoraite, 2013):

- Improvement of a company image;

- Increase of audience volume;

- Possibility to choose the audience;

- An interactive relationship with costumers;

- Effective trade;

- Marketing dynamics.

In order marketing objectives would be achieved, managers and academics apply Jeromy McCartthy's marketing mix called 4 Ps marketing mix. 4 Ps marketing mix is a combination of many factors which can be measured to meet the market needs and to simplify managerial activities (Kalyanam, McIntyre, 2002). According to McCarthy's 4 Ps marketing mix consist of: product, price, place and promotion. Every Ps cover a number of twelve managerial policies which are described by Borden in the early 1964, but adopted in marketing strategy till nowadays. 


\section{The International Journal}

ENTREPRENEURSHIP AND SUSTAINABILITY ISSUES

ISSN 2345-0282 (online) http://jssidoi.org/jesi/

2018 Volume 5 Number 3 (March)

http://doi.org/10.9770/jesi.2018.5.3(15)

In terms of twelve managerial policies, Borden (1964) explains that it is important to create: 1) a list of the important elements or ingredients that make up marketing programs; 2) a list of the forces that bear on the marketing operation of a firm and to which the marketing manager must adjust in his search for a mix or program that can be successful.

The 4 Ps marketing mix was proposed for traditional marketing. Since the business environment has changed, two different approaches - the revisionists' and the conservatives' views originated. The conservatives claim that 4 Ps model might be adopted to new context of marketing (Möller, 2006). Contrary to conservatives, the revisionists state that 4 Ps marketing mix model is internally oriented and Schultz (2001) claims that todays' market place needs externally oriented model. Internet marketing strategy must be customer oriented and pay strong attention to the relationship with the customer, which is not according to internally oriented model (Propovic, 2006; Möller, 2006). A common view of all revisionists is that the most important focus must go to customer orientation and according to this view the 4 Ps marketing mix model is applied.

Authors offered some corrections to 4 Ps marketing mix. For instance, Lawrence et al. (2000) offered to add two more Ps: people and packaging; and include this mix to the concept of 5 Ps marketing model, which includes paradox, perspective, paradigm, persuasion and passion. Prandelli and Verona (2006) proposed 3 Cs model: content (website and platform), community (interaction platform and relational capability) and commerce (including the 4 Ps: product, price, place and promotion). Even more 4 Ps were proposed to add (Precision, Payment system, Personalization, Push and Pull) to already existing 4 Ps marketing mix. Dominici (2009) describes additional 4 Ps in the 8 Ps'model (Juozapavičiūte, 2015):

- Database management systems provide the opportunity to increase accuracy of target segments determination and market positioning in digital context;

- Security and friendly-user environment - the components that must be ensured in payment systems;

- Personalization supports the adaption and determination to customers' needs and expectations;

- Push and Pull regards the choice of trade-off among active communication policies (push) and communication on users' demand (pull).

In summary, internet marketing is a rapidly growing area and has many benefits to customers and organizations. Costumers might find easily and fast the product or service they need on the Internet and the business has the opportunity to attract more target groups and to maintain close relationship with already existing clients. However, the needs and expectations of customers growing every day, they want to buy fast, easily, anytime, anywhere. Thus, it is a challenge for companies to determine efficient internet marketing strategy and to apply it in the practice.

\section{Qualitative criteria of internet marketing development}

Neither internet marketing quality nor qualitative criteria of internet marketing are defined in the literature. The novelty of internet marketing forcing the professionals of this area to look for new opportunities and to meet current and future customers' needs and expectations, which are often related intangible features such as trade mark, its' image and design, interaction with companys' image and reputation (Limba, Jurkute, 2013).

Forbes (2012) announce that any business must admit the power of a great design for customers' experience. Design-oriented business has the advantage, because the first thing what customer pays attention to - is an image, design of graphic, brand, product, interior, web and service design. For instance, the customer knows quickly if he likes the design or not, if the Web site is good or bad. Design-oriented companies put design at the heart of their 
company to build innovation and to constantly improve products, service and marketing trends. They recognize that a great design guarantees the differentiation, customer loyalty and higher profits (Swann, 2012).

Internet market orientation covers generation of information: collecting customers' information, development of customers'databases and responding to customers' demand. Since the Internet has changed the customers'behaviour, business had to adapt to the changes and focus on individualized and convenient services such as search function development in order to preserve the customers' loyalty and to stay competitive (Srini et al., 2002). Besides, the authors claim that Internet users assess the convenience and design of the website. Moreover, Lee and Kozar (2006) submite that companies which invest to flexibility of its' website can achieve corporate financial and performance of the website. The website must recognise the features of customers in order to make the enjoyable browsing on the website. Website design has important and positive influence to customers' satisfaction (Szymanski, Hise, 2000). Internet marketing is inseparable process, which helps to determine the target groups and provide information about products and services through the Internet to increase the sales.

Some authors emphasize importance of information quality, but include system and service quality as well (Sun, 2010). Based on Wixom and Todd's (2005) prepared model of technology use, the $3 \mathrm{Q}$ model was proposed, which includes three main aspects of information quality, system quality and service quality. The model separates the beliefs and attitudes about the system from the beliefs and attitudes about the using system. The model interprets that system quality explains the structural attributes of e. commerce system: availability, adaptability, response time. Information quality captures the content, which includes factors such as completeness, accuracy, format, currency. Step back to qualitative criteria of design, the literature of website quality says that system and information quality are important elements in the perception of website quality (Liu, Arnett, 2000).

Customer satisfaction is an important element in marketing practice and most companies admit that customer satisfaction is necessary "strategic imperative" (Mittal et al., 2010). On the one hand Hauman et al. (2014) confirm that customer satisfaction has a positive influence for customer loyalty and customer willingness to pay. On the other hand, customer satisfaction affects customers for a short time period because business operates in a very competitive environment. Because of that, companies must build long-term relationship with customers and pay attention to customer-company identification, which is described as the feeling of belongingness to an organization. The customer-company identification positively affects customers' in-role and extra-role behaviours, loyalty and willingness to pay (spending). Moreover, the customer-company identification is an active, selective and volitional psychological process in which customer selects the company by its' own desire, the competitors meet the problem to attract identified customers (Sen, 2003).

The topic of loyalty has been widely analysed for decades. E-loyalty is the continuation of the traditional loyalty to e. commerce. E-loyalty is the customers' loyalty to electronic retailer (Turban et al., 2002). From this view of point, there is no important difference between customer loyalty and customer e-loyalty. Xiaojuan, Ling Sia (2003) connected four factors, which are described as four staged perceptual elements, which form the customers' loyalty: confirmation of expectations, satisfaction, trust, sense of belonging. The authors combined the e-loyalty wheel of those four factors. Gong, Nam (2016) defines creative customers behaviors as positive outcomes for organizations because such behaviors lead to the improvement in customer satisfaction and loyalty. Companies' social responsibility can also increase customers' loyalty (Eteokleous et al., 2016; Hadjikhani et al., 2016).

Expectation is the first step when customer is in the process of decision making to purchase or not. The Internet provides more convenient to customers - they can easily reach the vendors' information about brand, reputation, and product or service evaluation. The Internet provides wide option opportunities for customers so their expectations are increasing more and more. In order to satisfy costumers' expectations companies need to 


\section{The International Journal}

ENTREPRENEURSHIP AND SUSTAINABILITY ISSUES

ISSN 2345-0282 (online) http://jssidoi.org/jesi/

2018 Volume 5 Number 3 (March)

http://doi.org/10.9770/jesi.2018.5.3(15)

improve their offerings. However, it is important to mention that companies must promise only as much as they really can implement, otherwise customers will get the dissatisfaction. In terms of online transactions, satisfaction is measured according to customers' behaviour on the website. The customer stays longer on the website and search for information. As a result, the chance of repeated buying is growing (Juozapavičiūtè, 2015).

Trust is an important element in e-loyalty wheel (Gefen, 2002). When the customers are satisfied about online purchase, the products or services, they are more willing to trust the vendor later (Davidavičienè, Sabaityte, 2014). The chance of sharing the information with the vendor, the decision of using the service again and accepting further offers of the vendor is increasing. Sense of belonging is the continuation of trust. This emotional connection is treated as high solidarity. If the customer comes to this stage, the possibility of re-purchase is increasing much more and the loyalty is formed exactly in the stage of sense of belonging. Moreover, if the vendor builds the online community, the customers will be more willing to attend it and makes them feel committed to online vendor. The positive feedback from the online communities will increase the chance of repurchasing; moreover, the members will be less afraid of sharing the personal information with the vendor. Getting the personal information is very important to the company, because it is the best way to build an effective loyalty programs and maintain the relationship with customer (Xiaojuan, Ling Sia, 2003).

Haumann et al. (2014) also highlight the importance of effectiveness of loyalty programs. They state that competitive actions such as competitive advertising influence the success of loyalty programs to maintain customer loyalty over time. Carrington, Neville (2016) state, that customers play very important role in produsing goods, so their loyalty is even more important.

To sum up different aspects, which influence the success of internet marketing, are analysed: brand, website design, level of reputation, accessible, accuracy, flexible information, secure information and data protection, customer satisfaction, expectations, trust, loyalty. In order to abridge the aspects, the four main criteria have been determined: design, information distribution channels, customer satisfaction and customers' e-loyalty.

\section{Investigation of Qualitative Criteria for Internet Marketing Development}

Research methodology. The qualitative research method was chosen - experts opinion survey by structured interview or questionnaire form. This method was chosen in order to dig deeper into the problem, while the quantitative research is focused on the extent and spread of the phenomenon (Baley, 1995). Qualitative research allows obtaining various information, broadening the issue and analysing it in a broader context. Interview is considered as one of the most effective qualitative research methods, which provides detailed answers, especially to open questions (Tidikis, 2003). Of all the types of interviews the expert interview was selected. The interview was carried out according to pre-formulated questions and respondents were asked by the same procedure.

The questionnaire was made in accordance with the principles of drawing up the questionnaire. The objective of the research was introduced; respondents were familiar with the issue of the research. Moreover, it was noted that the questionnaire is aimed to find the experts' insights about qualitative criteria of internet marketing determination and application. The answers are submitted as the personal opinion and evaluation. The questionnaire indicates major explanations and instructions on how to fill in a certain part of the questionnaire.

The problem of a sample size in quantitative research has been analysed sufficiently. However it is hard to determine what sample size should be held in qualitative research. The sample size depends on phenomenon details of the research, strategy of the research, informativeness of collected data and method of data collection. Applying interview, the proposed sample size is from five to thirty people, in this case nine respondents have been chosen. Qualitative research findings are more closely related to the investigators' analytical capacity and 
testing of selected cases informativeness, than the sample size of the problem (Bitinas et al., 2008). As a result, the sample size problem is not that much important by applying qualitative research method.

The experts have been chosen according to the activity areas, it was important that experts would be related to internet marketing. The information has been looking on the Internet. After selecting the experts, it was contacted personally. The researcher was proposed to the experts, as well as the problem of the research and the goal: according to the experts, to figure out the concept of internet marketing quality; to determine the qualitative criteria, which could be adapted by evaluating internet marketing; mark out the internet marketing development problems, solutions. Most of the experts wanted to stay anonymous, but agreed to specify the occupied functions. In order to keep the anonymity the experts are named anonymously, such as Expert A, Expert B etc. and activities specified. Nine experts' opinions are analysed. Moreover, the accuracy of decision and evaluation is sufficiently high when the number of experts reach nine, so this number of experts is enough to obtain accurate information. Those methodological assumptions set out in classical test theory. It says that aggregate decision reliability and decision-makers number connects fast fading nonlinear connection. In the modules of aggregated experts' evaluation which are connected with equal weights, small groups of experts' decisions and evaluations accuracy do not descend to large group of experts' accuracy of decisions and evaluation (Baležentis, Žalimaitè, 2011).

From the experts who were performing in the survey, nine experts have been chosen:

- Expert A - e. marketing project manager. Field of activity - retailer of domestic appliances and electronics leader in Lithuania.

- $\quad$ Expert B - e. marketing department director. Field of activity - Bank.

- $\quad$ Expert $\mathrm{C}$ - marketing Project manager. Field of activity -Insurance.

- Expert D - Co and Director. Field of activity - information and communication. Lector of e. marketing.

- Expert E - Trade Marketing Project Manager. Field of activity - a mobile communications company operating in the Baltic countries.

- Expert F - Head of Marketing and Communications. Field of activity - advisory services.

- Expert G - Brand Manager. Field of activity - trade and service company with a well-developed e. marketing network in Lithuania.

- Expert H - The leader of electronic channel management group. Field of activity - a mobile communications company operating in the Baltic countries.

- $\quad$ Expert I -Online marketing manager. Field of activity - trade and service company with a well-developed e. marketing network in Lithuania.

Since the goal of the research is to figure out the concept of internet marketing quality and to determine the qualitative criteria, which could be adapted by evaluating internet marketing, the experts above have been chosen from different activity areas. However, all of the organizations they are working for, developing internet marketing or even provide the internet marketing services to other companies. By formulating questions of the survey, the aim was to find out the opinions of experts about internet marketing development, its' problems and solutions as well.

Research Data Analysis. In the beginning of the first questions' analysis, it was noted that the criteria will be accepted as the applicable qualitative criteria in order to measure the internet marketing quality, if more than a half experts agree or totally agree with the statement. With the first statement that the literature clearly determines the concept of internet marketing quality, two out of nine experts disagree or totally disagree. However, four experts are not sure, so the statement cannot be evaluated properly. Overall, it should be noted that this question must be discussed, because there is no clear point of view neither between the authors nor the experts. In terms of suggested criteria design, it could be applied as qualitative criteria, because five out of nine experts agree or 
totally agree with the statement, which is more than a half. Online distribution channels could be also applied as the qualitative criteria, because five out of nine experts agree or totally agree with the statement. The survey results demonstrate that eight experts agree or totally agree with the customer satisfaction as a criteria and six out of nine experts agree or totally agree with the statement that e-loyalty could be applied as the qualitative criteria. Overall, all four qualitative criteria should be analysed in terms of internet marketing quality development and measurement.

According to second questions' answers, experts provide their insights about internet marketing quality. According to the experts internet marketing is qualitative if following aspects are achieved:

- Customer satisfaction (Experts A, B, D);

- ROI (Return on Investments) generation (Experts A, H, I);

- Accessibility anytime (24/7) and anywhere (via different online distribution channels) (Experts B, E, G);

- Target audience extension; customer involvement (Experts B, E, G).

To sum up the factors above internet marketing quality is: in accordance with the basics of marketing concepts, quality can be defined as reaching the consumers' satisfaction level, efficient use of cyberspace for potential users' involvement and target audience extension, and ROI generation for the company.

Respondents also were asked which of the following mentioned qualitative criteria is central according to the development of internet marketing quality. By this question, experts have been asked to distinguish the most important criteria or to propose the additional one, which, according to them, could be applied in the process of internet marketing quality evaluation. The experts' opinions diverged in Figure 1.

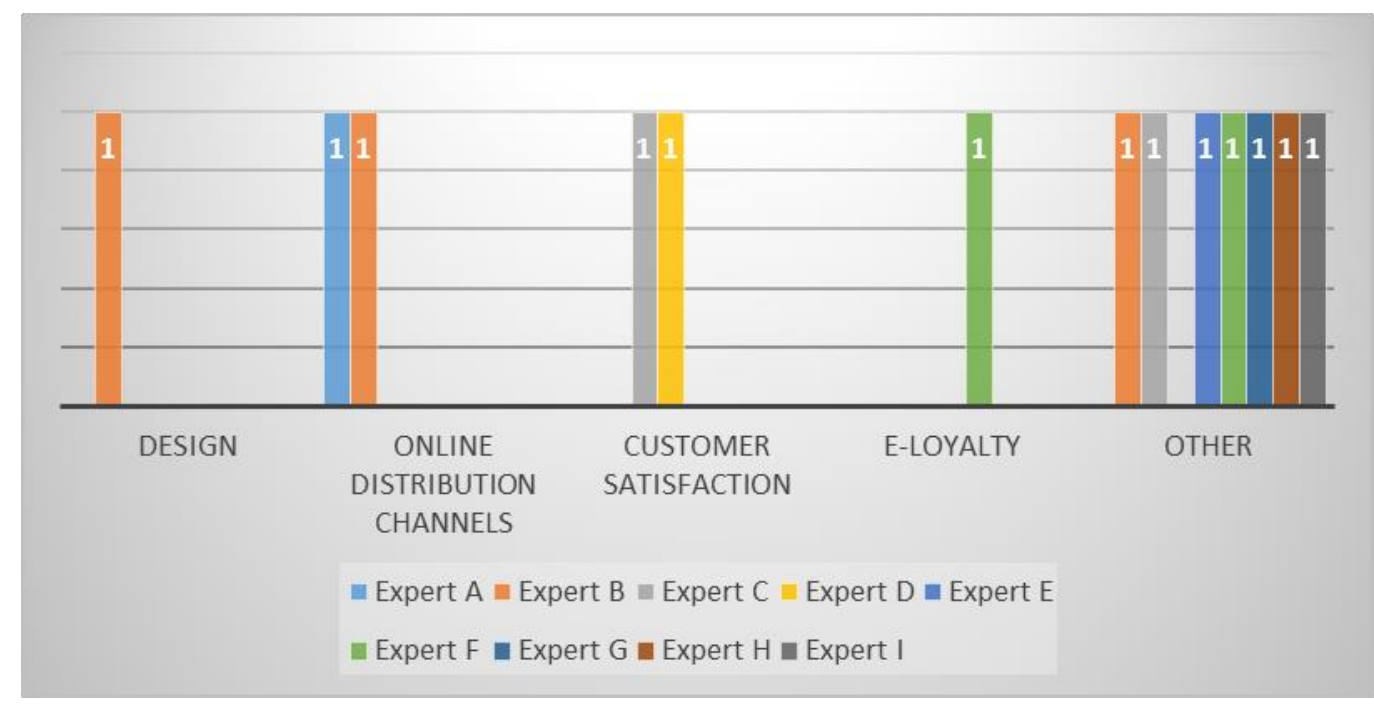

Fig.1. Central qualitative criteria for internet marketing

Source: authors

The Figure 2 shows that experts have different opinions about the central criteria. The experts were asked to exclude one of the following criteria or to provide the additional one. However, most of the experts provide few of most important criteria and additional as well. Experts A and B exclude online distribution channel as one of the most important criteria, but Expert B also thinks that design should be included between central criteria and provides additional criteria Google keywords - content optimization. Experts agree or totally agree with those criteria in the first question as well. The variety of opinions can be perceived. The experts do not provide one evolved criteria, but also it should be noted that all criteria have been chosen at least once. The online distribution 
channels and customer satisfaction are criteria, which have been chosen twice, but it could not be said that according to the survey they are the central ones, because two out of nine choices would be no lens. On the other hand, the answers to this question bring us to the result that the importance of this issue is really deep and important, because it is hard to determine common criteria. Overall, two of the experts note that it cannot be distinguished one criterion, the complex of measures should be applied and they should be adopted all together, not one by one. In addition, consideration should be given to the purpose of the company and marketing strategy, what company is going to achieve. Overall, online distribution channels and customer satisfaction have been chosen twice, design and e-loyalty once. Additional criteria could be such as Google keywords - content optimization; consistent and long-term strategy; new customers' number; conversions; CPA, CPM and ROI.

Further the experts provide significant criteria, which could be used in order to evaluate the website design. Interesting fact is that some of criteria repeats by experts. Attractiveness is repeated by Experts C and E; Usability - by Expert C and D; Clarity of display - Experts B and E. It could not be said that one or another criteria is the most important, because some users focus on one and other users to totally other subjects. Overall, criteria such as attractiveness, usability and clarity of display have been mentioned the most by the experts. Some other mentioned criteria are as follows: time spend reading the content; an opened page number; friendliness; SEO; the mutual link with social networks and the related external websites; adaption to specific product/service (visualization); working links and functions of the website; user involvement; CES indicator; implemented goals of website developer.

According to the answers of experts, the website design decision could be added with the elements, which could help evaluating the website design (see Figure 2).

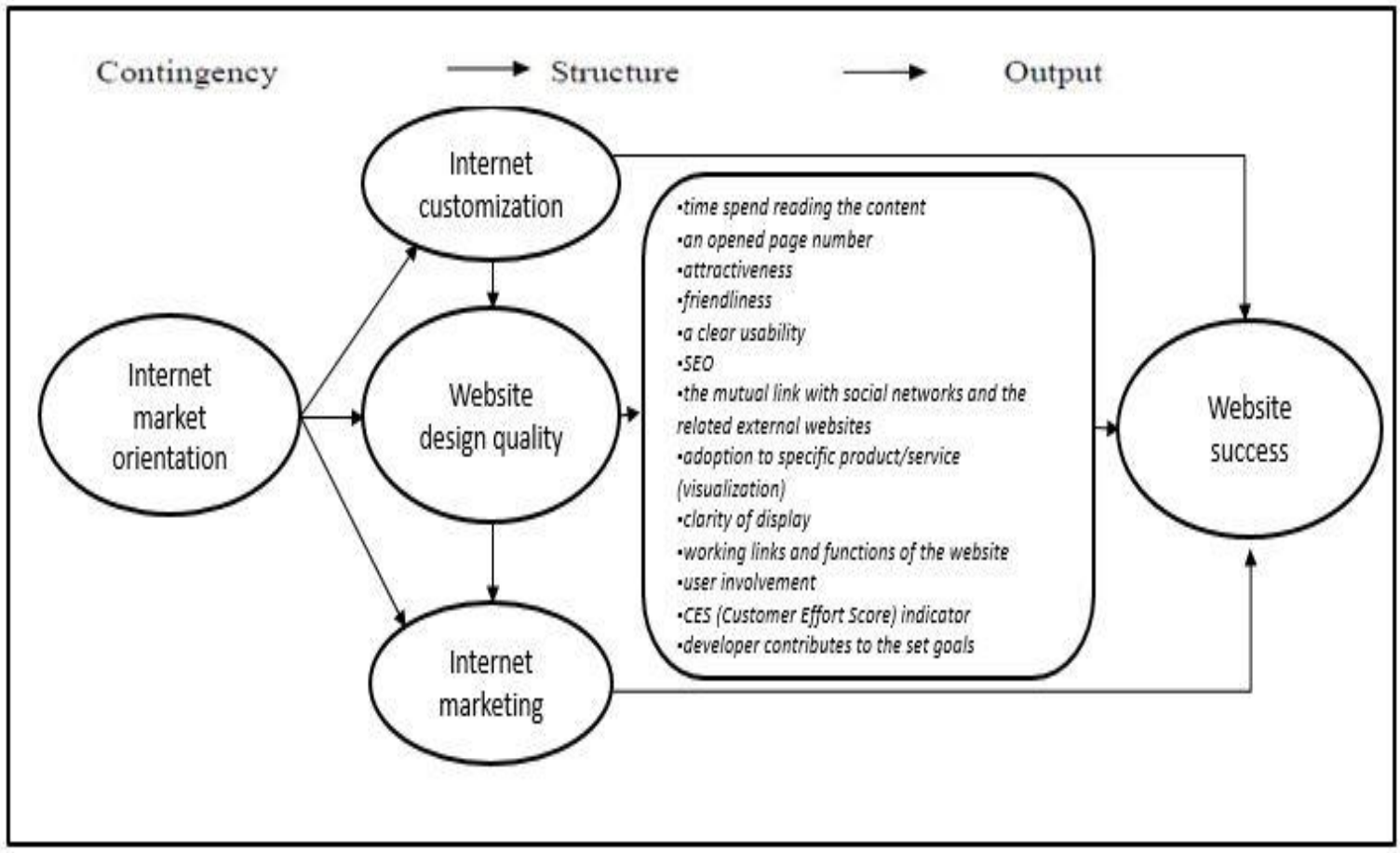

Fig.2. Completed website design decision

Source: authors 


\section{The International Journal}

ENTREPRENEURSHIP AND SUSTAINABILITY ISSUES

ISSN 2345-0282 (online) http://jssidoi.org/jesi/

2018 Volume 5 Number 3 (March)

http://doi.org/10.9770/jesi.2018.5.3(15)

Overall, it can be said that internet marketing faces variety of questions. It should not be highlighted one main emarketing qualitative criteria, because it depends on the goals of the company, marketing campaign and other aspects, which creates different issues. It is very important that experts suggest different opinions, because it only proves that organizations face different problems and they need to be solved in variety of ways.

\section{Designing the Internet Marketing Qualitative Criteria Application Model}

Designing methodology. Since the qualitative criteria are proposed and approved by the experts during the qualitative data analysis, it is beneficial to create the application model of internet marketing qualitative criteria, which could explain the value of the criteria and explain future applications. Scientific modeling is the creation of abstract or conceptual models. The science offers a wide range of methods and theories about the various kinds of scientific modeling. The main theory about scientific modeling is based on theories of philosophy, systems and knowledge visualization. Modeling is an essential and integral part in scientific activity.

Model analysis. The application model of internet marketing qualitative criteria (see Figure 3) is developed on the basis of:

- Analysis of qualitative criteria of internet marketing development and the issues setting;

- Analysis of qualitative criteria of internet marketing integration to e. business strategic development;

- Qualitative data analysis.

The model of internet marketing qualitative criteria starts with the input object of a short term goals, where the qualitative criteria are included: design, online distribution channels, customer satisfaction and e-loyalty.

Design. Forbes (2012) announce that any business must admit the power of a great design for customers' experience. Design-oriented companies put design at the heart of their company to build innovation and to constantly improve products, service and marketing trends. They recognize that a great design guarantees the differentiation, customer loyalty and higher profits. A well-designed website grants the customer to find the company whenever they trying to do it. A great content of the website helps customer to find it through search engines. Moreover, the website most of the times is one of the first touchpoints though which the potential customer will start building the trust with the company (Greenberg, Kates, 2014). Furthermore, the qualitative study determines that design should be adapted in the process of internet marketing quality development.

Online distribution channels. The literature (Greenberg, Kates, 2014) pays attention to digital media channels in order to reach the customers. On the one hand, the customers want to reach the information through the most convenient ways to them. On the other hand, information quality and distribution is also important from the business perspective. The variety of distribution channels help business collecting more requisite information about the customers and build the personalization. Business sites such as aheadWorks (2015), e. commerce platform (2015), eMarketer (2014) pays especially strong attention to online distribution channels as one of the most important trends for e. marketing. Moreover, the qualitative studies' results reveale that online distribution channels should be applied as the qualitative criteria for internet marketing.

Customer satisfaction. Chaffey (2009) declares that the most successful internet marketing factor to meet the needs of customers is satisfaction. According to analysed literature the customer satisfaction has been proposed as a qualitative criteria to internet marketing development. Even more the experts of qualitative study agree that customer satisfaction is an important criteria in internet marketing evaluation. 
E-loyalty. E. business is based on customer orientation, so it is important to recognize customers' needs and expectations in order to maintain the competitiveness and customers' loyalty (Turban et al., 2002). E-loyalty is also accepted as the qualitative criteria for internet marketing in the qualitative survey.

In order to create or improve the internet marketing quality the development process should be started from the qualitative criteria (mentioned above) adaption in a short time of period. Important aspect is that the efficiency will be reached if the complex of measures will be adapted. One of criteriation adaption is not adequate, because successful business has to follow the internet marketing trends, set the objective goals and adapt to fast changes in the market.

After the complex of measures is adapted and internet marketing meets the requirements of the qualitative criteria set, the following stage is solutions. Solutions should be implemented in a mid term of period in order to solve the rising poblems in the process of internet marketing quality building. Variety of problems have been determined during the qualitative survey. Experts agree that the most common problems are goals setting; lack of resources and budgets; opportunity to measure; perception problems; huge flow of information; customer interest; mobile friendliness; standing out from the others; customer loyalty. The internet marketing quality development will be more successful if at least the most common problems will have determined solutions. However, the stage of solutions implementation might bring benefit to organizations in order to prevent at least the most common rising problems.

The last stage of successful internet marketing quality developmet is positive $\boldsymbol{R O I}$ generation, which accoding to the modeling theory is based on output object. In the long perspective every business needs to generate positive ROI. If there are no profit for the company, none of internet marketing goals will bring the benefit to organization. After the complex of qualitative criteria is adapted and solutions implemented in order to reach the internet marketing quality, the result should be reached: obctive determination of internet marketing goals and strategy; sufficient resources (such as programming resources, competent marketing professionals; internet marketing knowledges (know-how) in the organization); elements for internet marketing measurement and evaluation; customer involvement; customer trust and loyalty building. The results above would bring the organization to successful ROI generation.

Overall, the point of the application model is to achieve the positive ROI through the qualitative criteria and solutions adaption in the process of internet marketing quality development. Moreover, the model might be adapted in the process of creating internet marketing quality or in the process of improving the already existing internet marketing quality. In addition, the aplication model is based on two perspectives: to implement customer oriented internet marketing (adaption of qualitative criteria) and business perspective, which aims to generate positive ROI. 
The International Journal

ENTREPRENEURSHIP AND SUSTAINABILITY ISSUES

ISSN 2345-0282 (online) http://jssidoi.org/jesi/

2018 Volume 5 Number 3 (March)

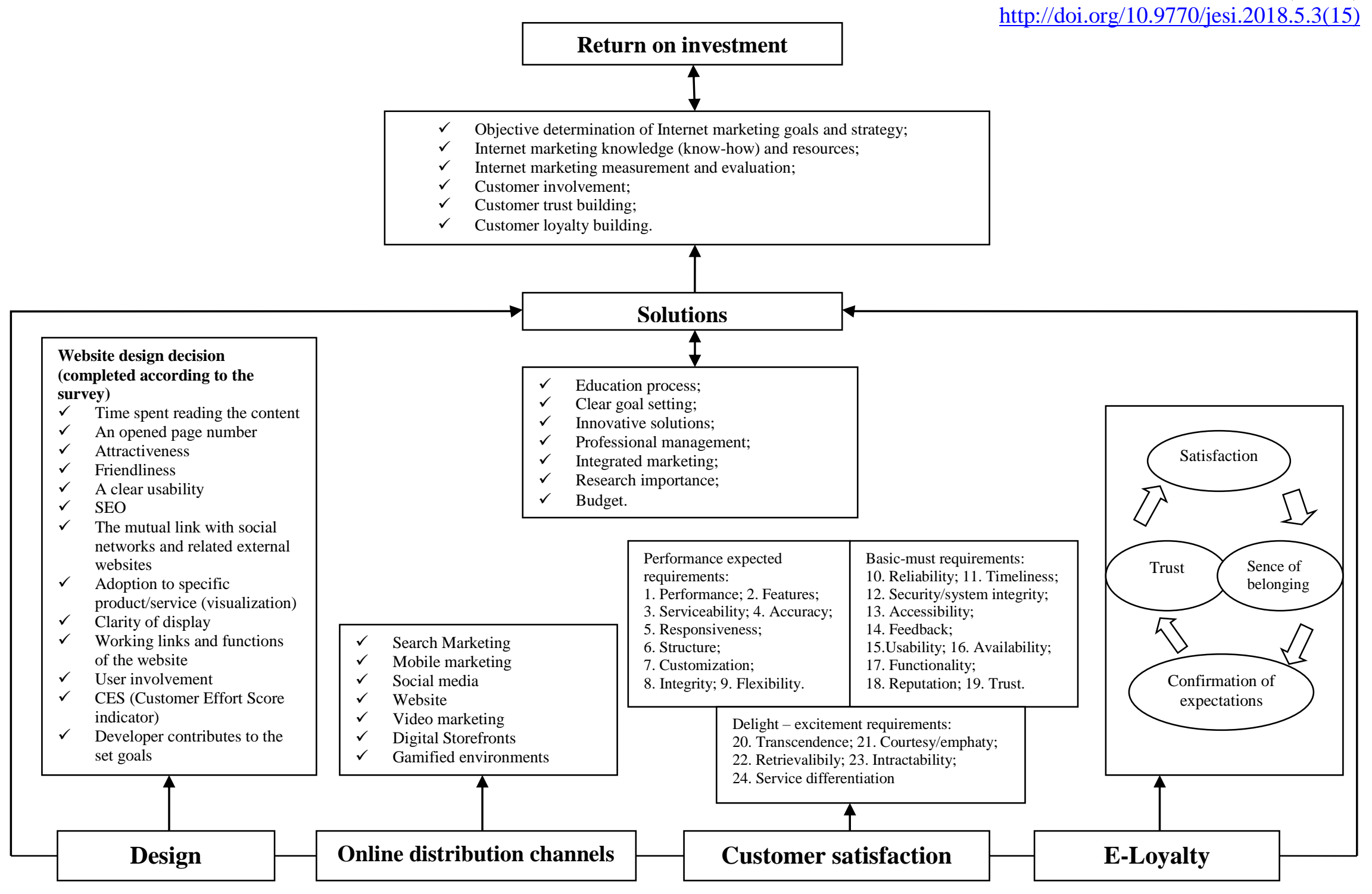

Fig.3. Internet marketing qualitative criteria application model Source: authors 


\section{Conclusions}

1. Universal concept of internet marketing is not defined, however it has multiple quantitative and qualitative aspects. Qualitative aspects have been the focus of this paper. Principal emerging qualitative criteria for internet marketing assessment are design, online distribution channels, customer satisfaction and e-loyalty. Similarly to other e. business phenomena, internet marketing may be approached from two perspectives - customers' and businesses'. In order to increase the efficacy of the internet marketing, as well as reach the positive performance measure ROI, it is very important to ascertain the customers. The qualitative criteria from customer experience shall be included in the assesment of the internet marketing quality.

2. Based on qualitative expert interview data analysis, it was determined that design, online distribution channels, customer satisfaction and e-loyalty are most important criteria of internet marketing asessment. Since the weight of individual criteria cannot be foretold by this one study, the complex of measures should be adopted in order to achieve the internet marketing quality. Also, the website design decision framework shall be developed according to experts' suggested criteria. The main problems facing the internet marketing campaign development are goal setting; lack of resources and budgets; opportunity to measure; perception problems; huge quantities and flows of information; customer interest; mobile usability and user-friendliness; differentiating from the others; as well as customer loyalty.

3. Based on the identified qualitative criteria pertinent for internet marketing, the qualitative model of internet marketing design and assessment is proposed. The initial input of the model is short term goal determination, where the complex of qualitative criteria are assumend. The next stage of the model is solutions' adaption in a mid term in order to solve the rising problems in the process of internet marketing quality building. Finally, the output of the model in a long perspective is a positive ROI generation, which is the final goal of any business and internet marketing campaign. Moreover, the model may be adapted in the process of creating new internet marketing campaigns or in the process of improving the already existing internet marketing campaign quality. In addition, the aplication model is based on two perspectives: to implement customer oriented internet marketing (adaption of qualitative criteria) and business perspective, which aims to generate a positive ROI.

\section{References}

Bailey, W. G. 1995. The Encyclopedia of Police Science, New York: State University of New York.

Baležentis A., Žalimaitė M. 2011. Expert Assessments for the Development of Innovations in the Analysis of Factors: Lithuanian Innovative Companies Assessment, Management theory and studies for rural business and infrastructure development, No. 3 Issue 27, pp. 23-31.

Balmer, J. M., Yen, D. A. 2017. The Internet of total corporate communications, quaternary corporate communications and the corporate marketing Internet revolution, Journal of Marketing Management, Vol. 33, Issue 1/2, pp. 131-144. https://doi.org/10.1080/0267257X.2016.1255440

Bitinas, B., Rupšienė, L., Žydžiūnaitė V. 2008. Qualitative Research Methodology. Klaipėda: College of Social Sciences.

Borden, N.H. 1964. The Concept of the Marketing Mix. Journal of Advertising Research, 24 (4), pp. 7-12.

Breakenridge, D. 2001. Cyberbranding: Brand Building in the Digital Economy, USA: Prentice Hall PTR Upper Saddle River, NJ. 
Carrington M., Neville B. 2016. Marketers are consumers too: integrating consumer-self in potential value creation, European Journal of Marketing, Vol. 50, Issue 5/6, pp. 1-46. https://doi.org/10.1108/EJM-03-2015-0185

Chaffey, D. 2014. Internet Marketing: Strategy, Implementation and Practice. ( ${ }^{\text {rd }}$ edition), USA.

Chaffey, D., Ellis-Chadwick, F., Mayer, R. \& Johnston, K. 2009. Internet Marketing. Strategy, Implementtion and Practice, Prentice Hall, Financial Times - Edinburgh.

Davidavičienè, V., Pabedinskaite, A.O., Davidavičius, S. 2017. Social networks in B2B and B2C Communication, Transformations in business and economics, Vol. 16, no. 1, pp. 69-84.

Davidavičienè, V., Davidavičius, S. 2014. Social networks in marketing communication - case of Lithuania, Scientific bulletin of National Mining University : scientific and technical journal = Науковий Вісник Національного гірничого університету : науково технічний журнал, Vol. 4 (142), pp. 101-107. http://ijbe-research.com/wp-content/uploads/2017/02/out_20.pdf

Davidavičienè, V., Sabaitytė, J. 2014. Tyrimų internetinès rinkodaros srityje analizè, Business: theory and practice, Vol. 15, no. 3, pp. 220-233. https://btp.press.vgtu.lt/article/14409/download/pdf/

Deighton, J. 2017. Rethinking the Profession Formerly Known as Advertising: How Data Science Is Disrupting the Work of Agencies, Journal of Advertising Research, Vol. 57, Issue 4, pp. 357-361. https://doi.org/10.2501/JAR-2017-045

Dominici, G. 2009. From Marketing Mix to E-Marketing Mix: a Literature Overview and Classification, PhD of Dep. S.E.A.F, Faculty of Economics, University of Palermo, pp. 1-7.

Eteokleous, P., Leonidou, L., Katsikeas, C. 2016. Corporate social responsibility in international marketing: review, assessment, and future research, International Marketing Review, Vol. 33, Issue 4, pp. 580 - 624. https://doi.org/10.1108/IMR-04-2014-0120

Fisher, R., Mohammed, R., Bernard, J., Jaworski \&Paddison, G. 2003. Internet Marketing: Building Advantage in a Networked Economy, USA.

Gefen, D. 2002. Customer loyalty in e-commerce, Journal of the Association for Information Systems, Vol. 3., pp. 27-51. http://aisel.aisnet.org/jais/vol3/iss1/2/

Greenberg, E., Kates, A. 2014. Strategic Digital Marketing: Top Digital Experts Share the Formula for Tangible Returns on Your Marketing Investment. ( ${ }^{\text {st }}$ edition), McGraw-Hill Education.

Gong T., Choi N. 2016. Effects of task complexity on creative customer behavior, European Journal of Marketing, Vol. 50, Issue 5/6, pp. 47-59. https://doi.org/10.1108/EJM-04-2015-0205

Hadjikhani, A., Woo Lee, J., Park, S. 2016. Corporate social responsibility as a marketing strategy in foreign markets: The case of Korean MNCs in the Chinese electronics market, International Marketing Review, Vol. 33, Issue 4, pp. 530 - 554. https://doi.org/10.1108/IMR-03$\underline{2014-0104}$

Haumann, T., Quaiser, B., Wieseke, J., Rese, M. 2014. Footprints in the Sands of Time: A Comparative Analysis of the Effectiveness of Customer Satisfaction and Customer - Company Identification over Time, American Marketing Association. Journal of Marketing, Vol. 78, pp. 78-102. https://doi.org/10.1509/jm.13.0509

Iqbal, M., Khan, A. A., Naseer, Q. 2013. A Legal Perspective of e-business and e-marketing for Small and Medium Enterprices, International Journal of Managing Infomartion Technology Vol. 5 Issue 1, pp. 1-11. https://arxiv.org/abs/1303.2675

Išoraite, M. 2013. Particularities of internet marketing strategy formation in 3rd International Scientific Conference "Practice and Research in Private and Public Sector“", pp. 53 - 57.

Juozapavičiūtè, I. 2015. Creation and application of qualitative criteria for development of internet marketing, Master‘s thesis. Vilnius: Mykolas Romeris University.

Kalyanam, K., McIntyre, S. 2002. The E-marketing Mix: a Contribution of the E-Tailing Wars, Academy of Marketing Science Journal Vol. 30 Issue 4, pp. 487-499. 
Korsakienè, R., Tvaronavičienė, M. 2012. The internationalization of SMEs: an integrative approach, Journal of Business Economics \& Management, Vol. 13 Issue 2, pp. 294-307. https://doi.org/10.3846/16111699.2011.620138

Lawrence, E., Corbitt, B., Fisher, J. A, Lawrence, J. \& Tidwell, A. 2000, Internet Commerce: Digital Models for Business (2 ${ }^{\text {nd }}$ edition), Wiley \& Sons.

Lee, Y., Kozar, K. 2006, Exploring the Relationship between Website Quality, Preference, and E-Business Performance: An Analytic Hierarchy Process (AHP) Approach, Decision Support Systems, Vol. 42, pp. 1383-1401. https://doi.org/10.1016/j.dss.2005.11.005

Limba, T., Jurkute, V. 2013. Brand development and enhancement of electronic marketing tools, Social Technologies, Vol. 4, pp. 130-148. https://www3.mruni.eu/ojs/social-technologies/article/view/485/448

Liu, C., Arnett, K.P. 2000. Exploring the factors associated with Web site success in the context of electronic commerce, Information Management, 38(1), pp. 23-33. https://www.sciencedirect.com/science/article/pii/S0378720600000495

Mittal, Vikas, Frennea, C. 2010. Customer satisfaction: A strategic Rewiew and Guidelines for Managers, Cambridge MA: MSI Fast Forward Series, pp. 131.

Möller, K. E. 2006. Comment on: The Marketing Mix Revisited: Towards the 21st Century Marketing by E. Constantinides, Journal of Marketing Management Vol.2 Issues 3, pp. 439-450.

Popovic, D. 2006. Modelling the marketing of high-tech start-ups, Journal of Targeting, Measurement and Analysis for Marketing Vol.14 Issue 3, pp. 260-276. https://link.springer.com/article/10.1057/palgrave.jt.5740186

Prandelli, E., Verona, G. 2006. Marketing in Rete, Milan: McGraw-Hill.

Schultz, D. E. 2001. Marketers: Bid Farewell to Strategy Based on Old 4Ps, Marketing News, Vol. 35 Issue 2, pp 1-7.

Sen, S. 2013. Consumer - Company Identification: A Framework for Understanding Consumers' Relationships with Companies, Journal of Marketing (April), pp. 76-88.

Shaltoni, A. M. 2017. From websites to social media: exploring the adoption of internet marketing in emerging industrial markets, Journal of Business \& Industrial Marketing, Vol. 32, Issue 7, pp. 1009-1019. https://doi.org/10.1108/JBIM-06-2016-0122

Srini S., Anderson, R., Ponnavolu, K. 2002. Customer loyalty in e-commerce: an exploration of its antecedents and consequences, Journal of Retailing, Vol. 78, pp. 41-50. https://pdfs.semanticscholar.org/87e2/27c309c8605a37bc77300315a940b581dc98.pdf

Sun, H. 2010. Transferring Attributes of E-commerce Systems into Business Benefits: a Realationship Quality Perspective, Journal of Electronic Commerce Research, Vol. 11 Issue 2, pp. 92 - 109. http://ojs.jecr.org/jecr/sites/default/files/11 2 p01.pdf

Swann, A. 2012. The Forbes, Retrieved from https://www.forbes.com/sites/gyro/2012/05/03/welcome-to-the-era-of-design/

Szymanski, D. M., Hise, T. R. 2000. E-Satisfaction: An Initial Examination, Journal of Retailing, 76 (3), pp. $309-322$.

Tidikis, R. 2003. Social Science Research Methodology, Vilnius: Lithuanian Law University Publishing Centre.

Turban, E., King, D., Lee, J., Warkentin, M., Chung, H. M. 2002. Electronic commerce: a managerial perspective. (2nd edition), New Jersey: Prentice Hall.

Tvaronavičienė, M. 2017. Clusters, Innovations and Energy Efficiency: if Relationship could be traced, Marketing \& Management of Innovations, Issue 2, pp. 362-391. https://doi.org/10.21272/mmi.2017.2-35

Wixom, B. H., Todd, P. A. 2005. A theoretical integration of user satisfaction and technology acceptance, Information Systems Research, Vol. 16 Issue 1, pp. 85-102. https://pdfs.semanticscholar.org/95ea/e3a82d9d1b01ca4eafd4922cd0f719517c32.pdf

Xiaojuan O., Ling Sia Ch. 2003. Customer Loyalty Strategy in the Internet Era, Journal of Information Systems, Vol. 19 , pp. 1736 - 1738. 
Tadas LIMBA is the Professor at Mykolas Romeris University, Lithuania. He has published over 30 articles in Lithuanian and foreign scientific journals, monograph, textbook, focused on e-government and e-business. His additional areas of research and expertise are - IT law regulation and policy; digital content, digital media, privacy and data protection issues. Tadas Limba is a member of Lithuanian Computer Society since 2007. Since 2013 he is Asia Center Board Member, South Korea's representative at Mykolas Romeris University. $\mathrm{He}$ is visiting professor at Zaragoza University in Spain. He plays an active role in international communication and development of joint double degree studies program with South Korea Dongseo University.

ORDCHID ID: orcid.org/0000-0003-2330-8684

Mindaugas KIŠKIS is the Professor at Mykolas Romeris University in Vilnius, Lithuania. Prof. M. Kiskis main areas of research and expertise are - intellectual property, technology (bio-nano-ICT) management, regulation and policy; digital content and digital media, privacy and data protection issues. Prof. Kiskis also works in e-business, innovation and entrepreneurship fields. Prof. Kiskis is a fellowships recipient with major foreign universities, including Visiting Professor at the East China University of Science and Technology (2013), Understanding Canada Scholar (2011), Fulbright Scholar at the Arizona State University (2007-2008), Markle Fellow at the Oxford University (2003) and other. Prof. M. Kiskis is also the serial entrepreneur, cofounder of three technology start-ups, active member of the knowledge society NGOs, also, the author of 4 monographs, 4 textbooks and 35 articles in Lithuanian and foreign publications.

ORDCHID ID: orcid.org/0000-0003-4269-375X

Gintarė GULEVIČIŪTÉ is a lecturer at Mykolas Romeris University, Lithuania. Her areas of interest are e-business, e-marketing, entrepreneurship, business communication and digital contents. She plays an active role in international communication and development of joint double degree study programs with South Korea Dongseo University.

ORDCHID ID: orcid.org/0000-0003-1974-3982

Andrius STASIUKYNAS is the Assoc. Professor and director of the Institute of Public Administration at Mykolas Romeris University, Lithuania. His main areas of research and expertise are - public and nonprofit-nongovernmental sectors management and development; public services management; public governance. Andrius Stasiukynas is the coordinator of the Net of Public Governance Competences (since 2016), member of Association of Energy Economics (since 2014); member of the National Working Group on European Structural Dialogue on Youth Policy (since 2014).

ORDCHID ID: https://orcid.org/0000-0002-2937-241X

Tomas PLÉTA is Communications and information system officer of NATO ENSEC COE. His areas of interest are e-business, emarketing, cyber security, energy protection and energy efficiency. He's an expert in cyber-security on which he has published in international journals.

ORDCHID ID: https://orcid.org/0000-0002-5376-6873

Ieva JUOZAPAVIČIŪTĖ got B. Sc. in Public Administration in 2013 and helds M. Sc. in Electronic Business Management from Mykolas Romeris University. She works as an assistant marketer at accounting company. Her areas of interest are e-commerce and emarketing.

ORDCHID ID: https://orcid.org/0000-0002-6116-2703

Copyright (C) 2018 by author(s) and VsI Entrepreneurship and Sustainability Center

This work is licensed under the Creative Commons Attribution International License (CC BY).

http://creativecommons.org/licenses/by/4.0/

(c) (i) Open Access 